\title{
Meningkatkan Pemahaman Konsep Matematika tentang Sifat-Sifat Bangun RuANG SEDERHANA MELALUi ContEXTUAL TEACHING AND LEARNING
}

\author{
Asiroha Sipayung \\ SD Negeri Tebet Timur 07 Pagi Jakarta Selatan \\ Jl Tebet Utara III Gandaria Utara Kebayoran Baru Jakarta Selatan, 12140, Indonesia \\ asirohasipayung4@gmail.com
}

Artikel diterima: 5 Agustus 2018, direvisi: 21 September 2018, diterbitkan: 30 September 2018

\begin{abstract}
Abstrak
Penelitian ini bertujuan untuk mengetahui pemahaman siswa terhadap konsep matematika tentang sifat-sifat bangun ruang melalui penerapan pendekatan Contextual Teaching and Learning. Metode yang digunakan adalah Penelitian Tindakan Kelas dan subjeknya adalah siswa kelas IV yang berjumlah 30 siswa. Hasil penelitian pada siklus I pertemuan 1 nilai rata-rata mencapai 62,00 sedangkan pada siklus I pertemuan 2 nilai rata-rata meningkat menjadi 67,50, siklus II pertemuan 1 76,33 dan siklus II pertemuan 2 82,00. Kesimpulan dari penelitian adalah pembelajaran dengan menerapkan pendekatan CTL dapat meningkatkan pemahaman konsep siswa di kelas IV. Ketuntasan belajar siswa pada siklus I hanya mencapai 13 orang atau 43,33\% dan yang belum tuntas belajarnya mencapai 17 orang atau 56,67 \%. Namun, pada siklus I pertemuan 2 ketuntasan belajar mencapai 16 orang atau 53,33\% dan yang belum tuntas belajarnya 14 orang atau $46,67 \%$. Untuk siklus II pertemuan 1 yang tuntas 22 orang atau $73,33 \%$ sedangkan yang belum tuntas 8 orang atau $26,67 \%$ dan untuk siklus II pertemuan 2 siswa yang tuntas 26 orang $86,67 \%$ dan yang belum tuntas 4 orang atau $13,33 \%$.

Kata Kunci: Pemahaman konsep, bangun ruang, pendekatan CTL.

Abstract (Enhancing Students' Understanding Concept of Mathematical Space Building Properties through Contextual Teaching and Learning)

This study aims to determine students' understanding of mathematical concepts about the nature of space building through the application of the Contextual Teaching and Learning approach. The method used is Class Action Research and the subject is 30 fourth-grade students. The results of this research in the first cycle of meeting 1 average score reached 62.00 while in the first cycle of meeting 2 average score increased to 67.50, cycle II meeting 176.33 and cycle II meeting 282.00. The conclusion of the study is that learning by applying the CTL approach can improve students' conceptual understanding in grade IV. Students' completeness of learning in the first cycle only reached 13 people or $43.33 \%$ and the unfinished study reached 17 people or $56.67 \%$. However, in the first cycle, the second meeting of learning completeness reached 16 people or $53.33 \%$ and 14 people had not yet completed their study or $46.67 \%$. For cycle II meeting 1 which was complete 22 people or $73.33 \%$ while the unfinished 8 people or $26.67 \%$ and for cycle II meeting 2 students who completed 26 people $86.67 \%$ and the unfinished 4 people or $13.33 \%$.

Keyword: Conceptual understanding, space building, CTL approach.
\end{abstract}




\section{Pendahuluan}

Pembelajaran matematika di berbagai jenjang pendidikan mulai dari Taman Kanak-Kanak sampai Perguruan Tinggi telah banyak memberikan kontribusi yang mendasar bagi perkembangan dan kemajuan intelegensi siswa. Bahkan, apabila kita memandang secara luas ternyata "pendidikan matematika telah memberikan kontribusi yang besar pada sejarah dunia dengan memberikan modelmodel matematika dalam studi ke alam semesta fisik. Misalnya, bangsa Yunani yang mengembangkan geometri sebagai studi ruang fisika" (Wahyudin, 2008: 14).

Khusus di Sekolah Dasar, mata membekali siswa dengan kemampuan berpikir logis, analitis, sistematis, kritis, kreatif, serta kemampuan bekerjasama. Kompetensi tersebut diperlukan agar siswa dapat memiliki kemampuan memperoleh, mengelola, dan memanfaatkan informasi. Sedangkan, ruang lingkup mata pelajaran matematika meliputi, bilangan, geometri dan pengukuran, serta pengolahan data. Namun, materi yang akan dibahas dalam penelitian ini adalah sifat-sifat bangun ruang di kelas IV.

Bangun ruang adalah bangun geometri yang memiliki tinggi atau ketebalan. Bangun ruang disebut juga bangun tiga dimensi. Bangun ruang dibentuk oleh daerah segi banyak yang disebut sisi, dan biasanya bagian datar dari suatu bangun ruang disebut permukaan. Bangun ruang pelajaran matematika bertujuan untuk

terdiri dari balok, kubus, bola, kerucut, tabung, dan prisma. Adapun, sifat-sifat dari setiap bangun ruang terdiri atas sisi, rusuk, dan titik sudut. Sisi adalah bidang yang membatasi suatu bangun ruang. Rusuk adalah garis yang merupakan pertemuan atau perpotongan sisi-sisi pada suatu bangun ruang, sedangkan titik sudut adalah titik potong dari beberapa rusuk.

Permasalahan di lapangan pada saat ini khususnya di kelas IV SDN Tebet Timur 07 Pagi Jakarta Selatan ada kecenderungan bahwa pemahaman siswa terhadap sifatsifat bangun ruang sederhana masih kurang. Hal ini terbukti dari kenyataan bahwa skor matematika siswa pada umumnya kurang dari 63, sedangkan skor maksimum ideal yang diaharapkan adalah 100 khususnya pada materi bangun ruang. Skor siswa ini benar-benar lebih rendah di bawah nilai Kriteria Ketuntasan Minimum (KKM) yang telah ditetapkan sekolah, yaitu 70. Guru matematika selalu berusaha mengembangkan metode pembelajaran untuk meningkatkan sikap ilmiah siswa, yang berdampak pada hasil belajar siswa (Razak dan Kamaruddin, 2018).

Permasalahan tentang masih kurangnya pemahaman siswa terhadap pembelajaran sifat-sifat bangun ruang memang tidak mutlak timbul dari kesalahan siswa itu sendiri, melainkan dari faktor lainnya. Kemampuan pemahaman matematis adalah kemampuan mengklasifikasikan obyek-obyek matematika, menginterpretasikan gagasan atau konsep, menemukan contoh dari sebuah konsep, dan menyatakan kembali konsep 
matematika dengan bahasa sendiri (Muna dan Afriansyah, 2016).

Beberapa penelitian yang telah mengkaji kemampuan pemahaman matematis dari tahun ke tahun dikaitkan dengan berbagai model pembelajaran, yaitu: Pembelajaran Kooperatif Tipe Team Assisted Individually (Pirdaus \& Afriansyah, 2016) dan Tipe Rotating Trio Exchange (Nuraeni \& Afriansyah, 2016); Aptitude Treatment Interaction (Pamungkas \& Afriansyah, 2017); Auditory Intellectualy Repetition Dan Problem Based Learning (Alan \& Afriansyah, 2017); dan Cooperative Learning Tipe Pair Checks dan Problem Based Learning (Supriatna \& Afriansyah, 2018).

Perlu disadari bahwa hal ini tentu ada pula kelemahan dan kekurangan dari berbagai pihak khususnya dari pihak guru, penyelenggaraan pendidikan baik dari faktor penguasaan konsep, faktor penggunaan metode, faktor penggunaan alat bantu/media pembelajaran, maupun faktor-faktor lainnya. Oleh karena itu, dalam hal ini pula peneliti akan mencoba berupaya membantu memecahkan permasalahan tersebut melalui penggunaan "Model Pembelajaran Contextual Teaching and Learning" dalam pembelajaran sifat-sifat bangun ruang sederhana untuk siswa kelas IV SDN Tebet Timur 07 Pagi Jakarta Selatan.

Penerapan dalam pembelajaran sifatsifat bangun ruang sederhana merupakan suatu kegiatan yang dilakukan untuk menjelaskan alur pemikiran secara sistematis tentang sifat-sifat bangun ruang

\section{Mosharafa: Jumal Pendidikan Matematika}

Volume 7, Nomor 3, September 2018

Copyright @ 2018 Mosharafa: Jurnal Pendidikan Matematika dengan tepat, bahkan dengan Contextual Teaching and Learning (CTL) ini siswa tidak terbatas pada materi yang ada pada sumber, akan tetapi bisa saja menambah dari sumber lain atau pun dari pengalaman di lingkungan sekitar. Dengan demikian, upaya penerapan pendekatan Contextual Teaching and Learning (CTL) dalam pembelajaran sifat-sifat bangun ruang sederhana tersebut bertujuan untuk memberikan dampak positif bagi peningkatan hasil belajar siswa, apalagi disajikan atau dikemas secara sistematis dan menarik berdasarkan fakta yang tidak terlepas dari konsep atau prinsip-prinsip suatu proses. Dalam prosesnya guru perlu berperan aktif dengan menekankan pada pemberian pengalaman secara langsung dan penemuan suatu masalah untuk mengembangkan kompetensi agar siswa lebih memahami dan mencintai materi itu sesuai dengan fungsinya.

Nurhadi (2004: 32) menjelaskan bahwa gambaran sederhana tentang penerapan pendekatan contextual Teaching and Learning (CTL) dalam proses pembelajaran perlu menekankan pada tujuh komponen, yaitu: 1) komponen konstruktivisme; 2) komponen inquiry; 3) komponen bertanya; 4) komponen masya-rakat belajar; 5) komponen pemodelan; 6) komponen refleksi; dan 7) komponen penilaian yang sebenarnya. Selain itu, melalui model pembelajaran kontekstual mengandung integrasi nilai-nilai karakter dalam mata pelajaran matematika (Maryati dan Priatna, 2017). 
Berdasarkan latar belakang di atas, maka kegiatan penelitian ini mengangkat judul; "Upaya Meningkatkan Pemahaman Konsep Matematika Tentang Sifat Bangun Ruang Melalui Penerapan Pendekatan Contextual Teaching and Learning". Hal ini dimaksudkan untuk memberikan ide atau gagasan bahwa penerapan pendekatan Contextual Teaching and Learning (CTL) dalam pembelajaran matematika terutama pada sifat-sifat bangun ruang cukup penting serta dapat meningkatkan hasil secara kelompok.

Latipah dan Afriansyah (2018) telah berhasil menerapkan Contextual Teaching and Learning (CTL). Pada penelitiannya, mereka berhasil meningkatkan kemampuan koneks matematis siswa melalui pembelajaran CTL.

Berdasarkan latar belakang masalah di atas, maka peneliti merumuskan masalah tersebut pada hal-hal sebagai berikut.

1. Bagaimana perencanaan pembelajaran dengan penerapan pendekatan Contextual Teaching and Learning $(\mathrm{CTL})$ ?

2. Bagaimana pelaksanaan dalam proses pembelajaran sifat-sifat bangun ruang sederhana melalui penerapan pendekatan Contextual Teaching and Learning (CTL)?

3. Bagaimana pemahaman belajar siswa dalam proses pembelajaran sifat-sifat bangun ruang sederhana setelah menerapkan pendekatan Contextual Teaching and Learning (CTL)? belajar siswa baik secara individu maupun sifat-sifat bangun ruang sederhana

Berdasarkan rumusan masalah di atas, maka tujuan penelitian yang ingin dicapai adalah sebagai berikut.

1. Untuk mengetahui perencanaan pembelajaran tentang sifat-sifat bangun ruang sederhana melalui pendekatan Contextual Teaching and Learning (CTL)

2. Untuk mengetahui pelaksanaan dalam proses pembelajaran tentang sifat-sifat bangun ruang sederhana melalui pendekatan Contextual Teaching and Learning (CTL)

3. Untuk mengetahui pemahaman siswa dalam proses pembelajaran tentang sifat-sifat bangun ruang sederhana setelah menerapkan pendekatan Contextual Teaching and Learning (CTL)

Manfaat dari pelaksanaan penelitian tentang penerapan pendekatan Contextual Teaching and Learning (CTL) dalam proses pembelajaran sifat-sifat bangun ruang ternyata banyak manfaatnya, baik bagi siswa, bagi guru, maupun bagi peneliti sendiri, di antaranya adalah sebagai berikut.

1. Manfaat Bagi Guru

Dapat dijadikan bahan pertimbangan bagi guru-guru dalam memilih media pembelajaran.

2. Manfaat Bagi Siswa

Siswa dapat memahami konsep matematika dengan alur pemikiran yang lebih aktif dan kreatif terutama pada pembelajaran sifat-sifat bangun ruang.

\section{Manfaat Bagi Sekolah}

Bermanfaat dalam rangka sumbangan ilmu terhadap proses pendidikandi sekolahterutama dalam meningkatkan 404
Mosharafa: Jumal Pendidikan Matematika Volume 7, Nomor 3, September 2018 Copyright $\odot 2018$ Mosharafa: Jurnal Pendidikan Matematika 
kualitas pembelajaran yang berhu-bungan dengan penerapan pendekatanContextual Teaching and Learning (CTL).

\section{Metode}

\section{A. Setting dan Subjek Penelitian}

Lokasi penelitian dilaksanakan di Sekolah Dasar Negeri Tebet Timur 07 Pagi Jakarta Selatan kelas IV.

Subjek penelitian adalah siswa kelas IV SDN Tebet Timur 07 Pagi Jakarta Selatan dengan jumlah siswa 30 orang siswa yang terdiri atas 19 siswa laki-laki dan 11 siswa perempuan. Adapun, yang menjadi subjek dalam penelitian tindakan kelas tidak hanya sebatas pada sosok siswa yang sedang mengikuti proses pembelajaran.

Pelaksanaan penelitian tindakan kelas terhadap kelas IV SD Negeri Tebet Timur 07 Pagi Jakarta Selatan, dilaksanakan 2 siklus atau 4 pertemuan. Pelaksanaan kegiatan pada semester genap tahun ajaran 2017/2018. Adapun pelaksanaannya sebagai berikut:

1. Siklus I pertemuan 1, hari Senin, $07 \mathrm{Mei}$ 2018

2. Siklus I pertemuan 2, hari Senin, 14 Mei 2018

3. Siklus II pertemuan 1, hari Senin, 21 Mei 2018

4. Siklus II pertemuan 2, hari Senin, 28 Mei 2018

\section{B. Prosedur Penelitian}

Prosedur penelitian dilakukan dengan cara melaksanakan kegiatan yang berbentuk siklus. Tiap siklus terdiri dari empat tahapan, yaitu tahap perencanaan, pelaksanaan tindakan, tahap observasi, dan tahap repleksi. Pada siklus pertama dari setiap tahapan terutama dari tahapan refleksi diharapkan muncul suatu permasalahan, sehingga perlu suatu perbaikan pada siklus selanjutnya, baik siklus II.

\section{Instrumen Penelitian}

Instrumen penelitian yang digunakan dalam penelitian ini adalah pedoman observasi, pedoman wawancara, catatan lapangan, dan kamera foto.

\section{Teknik Pengumpulan Data}

Dalam penelitian kualitatif, data diperoleh dari berbagai sumber, dengan menggunakan teknik pengumpulan data yang bermacam-macam (triangulasi), dan dilakukan secara terus menerus sampai datanya jenuh. Dengan pengamatan yang terus menerus tersebut mengakibatkan variasi data tinggi sekali.

Setelah data terkumpul maka dilakukan pengolahan data dengan tujuan untuk memberikan dukungan terhadap pencapaian tujuan penelitian terutama dalam hal kinerja guru dan aktivitas siswa yang selanjutnya dilakukan pengkajian dan analisis. Sedangkan, pengolahan data dilakukan melalui teknik analisis, yaitu:

Teknik Pengolahan Data Hasil Observasi, teknik pengolahan data yang dilakukan dari hasil observasi pada umumnya meliputi: 
1. Reduksi data

Reduksi data dilakukan dengan cara memilih dan memilah data yang diperlukan serta membuang data yang tidak digunakan atau diperlukan, sehingga data yang terkumpul itu benar-benar data yang valid.

2. Klasifikasi data

Klasifikasi data dilakukan dengan mengelompokkan data yang masuk dari semua siklus, baik siklus I maupun siklus II yang mengacu pada Rencana Pelaksanaan Pembelajaran (RPP), sehingga aktivitas guru dan siswa dapat diketahui baik yang diharapkan maupun yang tidak diharapkan.

\section{Display data}

Display data dilakukan dengan cara mendeskripsikan data yang diperoleh baik dalam bentuk narasi, uraian, maupun dalam bentuk tabel atau grafik.

\section{E. Teknik Analisis Data}

\section{Scoring}

Kriteria penilaian pada tes siklus I dan siklus II dilakukan dalam bentuk soal cerita yang berjumlah 5 (lima) butir soal, sedangkan bobot nilai tiap soal adalah 20 (dua puluh). Jika siswa menjawab semua soal dengan benar maka skor maksimum/ideal adalah 100.

2. Nilai rata-rata

Untuk mementukan nilai rata-rata hasil akhir tes adalah jumlah semuanilai dari masing-masing kelompok dibagi oleh banyak kelompok dengan kategori sebagai berikut.

Tabel 1

Kategori Nilai Rata-Rata Siswa

\begin{tabular}{|ccc|}
\hline No & Rentang Nilai & Kategori \\
\hline 1 & $90-100$ & Baik Sekali \\
\hline 2 & $70-89$ & Baik \\
\hline 3 & $50-69$ & Cukup \\
\hline 4 & $30-49$ & Kurang \\
\hline 5 & $0-29$ & Sangat Kurang \\
\hline
\end{tabular}

Keterangan:

Nilai 90 - 100 jika jawabannya lengkap

Nilai 70 - 89 jika jawabannya kurang lengkap

Nilai 50 - 69 jika jawabannya tidak lengkap Nilai 30 - 49 jika jawabannya salah semua

Nilai 0 - 29 jika jawabannya tidak diisi

\section{F. Indikator Keberhasilan}

Indikator penelitian tindakan kelas ini dapat dilihat dari beberapa kegiatan yang dilakukan selama berlangsungnya proses pembelajaran.

1. Keaktifan siswa dalam pembelajaran matematika mengalami peningkatan sebesar $75 \%$.

2. 92\% siswa Kelas IV SDN Tebet Timur 07 Pagi Jakarta Selatan mengalami ketuntasan belajar individual, nilai lebih dari 65 dalam pembelajaran matematika.

3. Target minimal yang ingin dicapai oleh peneliti yang sesuai dengan standar di Sekolah tentang Kriteria Ketuntasan Minimal adalah 65.

\section{Hasil dan Pembahasan}

Pelaksanaan penelitian terdiri dari dua siklus empat pertemuan dan dilakukan sesuai prosedur yang telah ditetapkan mulai dari perencanaan sampai 
pelaksanaan baik siklus I pertemuan 1 dan

2 maupun siklus II pertemuan 1 dan 2. Selain itu, selama proses pembelajaran dilakukan pula observasi mengenai aktivitas guru maupun aktivitas siswa yang dilaksanakan oleh observer melalui lembar observasi yang telah disiapkan sebelumnya. Bahkan dari hasil observasi tersebut dapat diketahui bahwa pemahaman siswa terhadap konsep matematika terutama pada materi sifatsifat bangun ruang menunjukkan adanya peningkatan terutama pada siklus I pertemuan 2. Untuk mengetahui lebih jelas tentang pembahasan ini, peneliti menguraikannya secara terperinci dalam setiap siklus sebagai berikut.

\section{A. Siklus I Pertemuan I}

Pada siklus I pertemuan 1 yang dilaksanakan pada tanggal 07 Mei 2018 aktivitas siswa sudah mulai terlihat adanya peningkatan dibandingkan dengan prasiklus, tetapi peningkatan tersebut tidak terlalu signifikan. Hal ini terbukti dari nilai rata-rata yang diperoleh siswa dari 58,17 pada prasiklus menjadi 62,00 pada siklus I pertemuan 1. Kemudian pada belajar kelompok nilai rata-rata yang diperoleh hanya mencapai 68 atau dengan kategori C (cukup). Masih rendahnya nilai rata-rata yang diperoleh siswa menandakan bahwa siswa masih merasa kesulitan dalam memahami konsep matematika terutama pada materi sifatsifat bangun ruang. Dengan demikian, pelaksanaan tindakan dalam siklus I pertemuan 1 ini masih memiliki kelemahan dan kekurangan, sehingga perlu adanya suatu perbaikan yang harus dilaksanakan pada siklus selanjutnya.

Kurangnya keaktifan, kerjasama, maupun keseriusan siswa dalam mengikuti proses pembelajaran pada siklus I pertemuan 1 tentu saja diakibatkan masih banyaknya siswa yang kurang fokus pada materi pembelajaran, kurangnya disiplin, kurang beraninya mengemukakan ide atau gagasan, dan sebagainya. Namun, kelemahan dan kekurangan tersebut pula tidak semata semuanya atas kesalahan dari siswa itu sendiri, tetapi mungkin pula disebabkan oleh masih banyaknya kekurangan dan kelemahan dari guru. Salah satunya adalah guru kurang memberikan motivasi belajar terhadap siswa. Padahal pemberian motivasi belajar tersebut sangat penting bagi kemajuan siswa.

Motivasi yang harus diberikan oleh guru banyak sekali bentuknya, terutama yang dikaitkan pendekatan Contextual Teaching Learning (CTL), di antaranya membimbing siswa dalam mengkonstruksi pengetahuan barunya, menekankan siswa untuk menemukan sendiri, mengarahkan siswa pada rasa ingin tahu, membimbing siswa dalam belajar kelompok, menggunakan alat bantu atau media yang tepat, mengadakan refleksi, serta melaksanakan penilaian yang objektif.

\section{B. Siklus I Pertemuan 2}

Pada pelaksanaan siklus I pertemuan 2, proses pembelajaran tampaknya sudah mulai kondusif, bahkan keaktifan, 
kerjasama, dan keseriusan siswa selama pembelajaran berlangsung cukup baik. Dalam belajar kelompok pun tampaknya tidak seperti pada siklus I pertemuan 1, mereka terlihat adanya kerjasama yang baik, saling berkomunikasi, dan saling membantu. Hal ini terbukti dari nilai ratarata yang diperoleh kelompok menunjukkan adanya peningkatan, yaitu dari 68 dengan kategori C pada siklus I pertemuan 1 meningkat menjadi 72 dengan kategori $\mathrm{C}$ pada siklus I pertemuan 2. Di samping itu pula, adanya peningkatan dari hasil belajar siswa secara individu, di mana pada siklus I pertemuan 1 nilai ratarata yang diperoleh hanya mencapai 62,00 sedangkan pada siklus I pertemuan 2 meningkat menjadi 67,50.

Adanya peningkatan yang cukup signifikan dari siklus I pertemuan 1 ke siklus I pertemuan 2 ini tentu berkat adanya motivasi belajar terhadap siswa, baik motivasi intrinsik maupun motivasi ekstrinsik. Motivasi intrinsik merupakan dorongan yang timbul dari dalam diri anak itu sendiri, seperti adanya kemauan untuk mendapatkan ranking, adanya rasa ingin tahu, adaya rasa malu apabila memperoleh nilai rendah, dan sebagainya. Sedangkan, motivasi ekstrinsik merupakan dorongan yang timbul dari luar, salah satunya dorongan dari guru.

Berdasarkan pembahasan tersebut, maka dalam memberikan motivasi atau dorongan terhadap siswa untuk belajar lebih baik, guru perlu berperan lebih aktif dalam setiap proses pembelajaran. Karena, walaupun pada siklus I pertemuan 408
2 ini sudah ada peningkatan dari siklus I pertemuan 1, guru hendaknya jangan cepat puas sebab masih banyak kelemahan dan kekuranganya.

\section{Siklus II Pertemuan 1}

Pada siklus II pertemuan 1 yang dilaksnakan pada tanggal 21 Mei 2018 aktivitas siswa sudah mulai terlihat adanya peningkatan dibandingkan dengan siklus I pertemuan 2 , tetapi peningkatan tersebut tidak terlalu signifikan. Hal ini terbukti dari nilai rata-rata yang diperoleh siswa dari 67,50 pada siklus I pertemuan 2 menjadi 76,33 pada siklus II pertemuan 1 . Kemudian pada belajar kelompok nilai rata-rata yang diperoleh mencapai 80 atau dengan kategori B (baik). Masih rendahnya nilai rata-rata yang diperoleh siswa menandakan bahwa siswa masih merasa kesulitan dalam memahami konsep matematika terutama pada materi sifatsifat bangun ruang. Dengan demikian, pelaksanaan tindakan dalam siklus II pertemuan 1 ini masih memiliki kelemahan dan kekurangan, sehingga perlu adanya suatu perbaikan yang harus dilaksanakan pada siklus selanjutnya.

Kurangnya keaktifan, kerjasama, maupun keseriusan siswa dalam mengikuti proses pembelajaran pada siklus II pertemuan 1 tentu saja diakibatkan masih banyaknya siswa yang kurang focus pada materi pembelajaran, kurangnya disiplin, kurang beraninya mengemukakan ide atau gagasan, dan sebagainya. Namun, kelemahan dan kekurangan tersebut pula tidak semata semuanya atas kesalahan 
dari siswa itu sendiri, tetapi mungkin pula disebabkan oleh masih banyaknya kekurangan dan kelemahan dari guru. Salah satunya adalah guru kurang memberikan motivasi belajar terhadap siswa. Padahal pemberian motivasi belajar tersebut sangat penting bagi kemajuan siswa.

Motivasi yang harus diberikan oleh guru banyak sekali bentuknya, terutama yang dikaitkan pendekatan Contextual Teaching Learning (CTL), di antaranya membimbing siswa dalam mengkonstruksi pengetahuan barunya, menekankan siswa untuk menemukan sendiri, mengarahkan siswa pada rasa ingin tahu, membimbing siswa dalam belajar kelompok, menggunakan alat bantu atau media yang tepat, mengadakan refleksi, serta melaksanakan penilaian yang objektif.

\section{Siklus II Pertemuan 2}

Pada pelaksanaan siklus II pertemuan 2, proses pembelajaran tampaknya sudah mulai kondusif, bahkan keaktifan, kerjasama, dan keseriusan siswa selama pembelajaran berlangsung cukup baik. Dalam belajar kelompok pun tampaknya tidak seperti pada siklus II pertemuan 1, mereka terlihat adanya kerjasama yang baik, saling berkomunikasi, dan saling membantu. Hal ini terbukti dari nilai ratarata yang diperoleh kelompok menunjukkan adanya peningkatan, yaitu dari 72 dengan kategori C pada siklus II pertemuan 1 meningkat menjadi 80 dengan kategori B pada siklus II pertemuan 2. Di samping itu pula, adanya peningkatan dari hasil belajar siswa secara individu, di mana pada siklus II pertemuan 1 nilai rata-rata yang diperoleh mencapai 76,33 sedangkan pada siklus II pertemuan 2 meningkat menjadi 82,00. Meskipun pada siklus II pertemuan 2 sudah meningkat maka ketuntasan belajar pada siklus ke II ini sudah mencapai 86,67\% dan siswa yang belum tuntas $13,33 \%$. Untuk itu terhadap siswa yang belum tuntas agar diberi bimbingan belajar dan diberi pengayaan.

\section{Penutup}

Berdasarkan rumusan masalah yang telah ditetapkan serta berbagai temuan yang diperoleh selama penelitian tindakan kelas, maka dapat disimpulkan sebagai berikut: 1) Langkah-langkah proses pembelajaran tentang sifat-sifat bangun ruang sederhana melalui penerapan pendekatan Contextual Teaching and Learning $(\mathrm{CTL})$ yang dilaksanakan pada siklus I maupun siklus I| telah sesuai dengan prosedur, yaitu terdiri atas kegiatan awal, kegiatan inti, dan kegiatan akhir. Pada kegiatan awal dilaksanakan kegiatan apersepsi dan penyampaian tujuan pembelajaran. Pada kegiatan inti pelaksanaannya mengacu pada tujuh komponen, yaitu komponen konstruktivisme, komponen inquiry, komponen bertanya atau Tanya jawab, komponen belajar kelompok, komponen pemodelan atau penggunaan alat peraga, komponen refleksi, dan komponen penilaian yang sebenarnya atau objektif; 2) Aktivitas siswa dalam proses pembelajaran 
http://journal.institutpendidikan.ac.id/index.php/mosharafa

tentang sifat-sifat bangun ruang ketuntasan belajar mencapai 26 orang dan sederhana sifat-sifat bangun ruang sederhana melalui penerapan pendekatan Contextual Teaching and Learning (CTL) ternyata pada siklus I pertemuan 1 masih banyak siswa yang kurang menunjukkan adanya keaktifan, kerjasama, maupun keseriusan selama mengkuti proses pembelajaran tersebut. Namun, pada siklus I pertemuan 2 tampaknya sudah mulai terlihat adanya keaktifan, kerjasama, maupun keseriusan siswa dalam mengikuti menunjukkan adanya peningkatan; dan 3) Pemahaman belajar siswa dalam proses pembelajaran tentang sifat-sifat bangun ruang sederhana setelah menerapkan pendekatan Contextual Teaching and Learning (CTL) ternyata pada siklus I pertemuan 1 pemahaman siswa masih kurang atau masih rendah, walaupun ada sedikit peningkatan di banding dengan hasil prasiklus yang hanya mencapai nilai rata-rata 58,17. Pada siklus I pertemuan 1 nilai rata-rata yang diperoleh siswa hanya mencapai 62,00. Sedangkan, pada siklus I pertemuan 2 nilai rata-rata yang diperoleh mencapai 67,50 untuk siklus II pertemuan 1 76,33 dan siklus II pertemuan 2 82,00. Adapun, ketuntasan belajar siswa pada siklus I pertemuan 1 hanya mencapai 13 orang atau $43,33 \%$ dan yang belum tuntas belajarnya mencapai 17 orang atau $56,67 \%$, pada siklus I pertemuan 2 ketuntasan belajar mencapai 16 orang atau 53,33\% dan yang belum tuntas belajarnya 14 orang atau 46,67\%, untuk siklus II pertemuan 1 mencapai 22 orang atau $73,33 \%$ dan siklus II pertemuan 2 410 86,67\%. Dengan demikian, dapat disimpulkan bahwa penerapan pendekatan Contextual Teaching and Learning (CTL) dapat meningkatkan pemahaman belajar siswa terutama pada materi sifat-sifat bangun ruang sederhana.

Berdasarkan temuan selama penelitian tindakan kelas serta ditunjang dengan kajian terotis, maka untuk penyempurnaan proses pembelajaran matematika dengan menerapkan pendekatan Contextual Teaching and Learning (CTL), penulis menyampaikan saran sebagai berikut: 1 ) Kepada siswa disarankan agar dalam mengikuti proses pembelajaran dengan menggunakan pendekatan Contextual Teaching and Learning (CTL) alangkah baiknya mengikuti sesuai langkah-langkah atau prosedur yang mengacu pada tujuh komponen, yaitu komponen konstruktivisme, komponen inquiry, komponen bertanya atau Tanya jawab, komponen belajar kelompok, komponen pemodelan atau penggunaan alat peraga, komponen refleksi, dan komponen penilaian yang sebenarnya atau objektif. Dengan mengikuti prosedur tersebut tentu saja proses pembelajaran akan lebih bermakna dan berjalan lancar. Di samping itu, keaktifan, kerjasama, dan keseriusan selama mengikuti proses pembelajaran akan meningkat, serta pemahaman hasil belajar pun akan meningkat pula. Sebagai saran terakhir bagi semua siswa adalah agar lebih ditingkatkan belajar untuk bertanya serta belajar mengungkapkan berbagai ide atau gagasan yang ada 
kaitannya dengan materi yang sedang dibahas, sehingga dengan banyak bertanya dan mengungkapkan ide atau gagasan tersebut akan timbul keberanian untuk bertanya dan mengemukakan pendapat; 2) Kepada guru disarankan agar penggunaan metode secara konvensional janganlah dijadikan focus atau target suatu keberhasilan. Akan tetapi, alangkah baiknya apabila penerapan pendekatan Contextual Teaching and Learning (CTL) diterapkan dengan prosedur yang tepat dalam berbagai mata pelajaran terutama dalam mata pelajaran matematika. Karena, dengan menerapkan pendekatan ini ternyata dapat meningkatkan pemahaman hasil belajar siswa. Hal ini terbukti dari hasil pembelajaran matematika pada materi menentukan sifat-sifat bangun ruang yang dilaksnakan di kelas IV SDN Tebet Timur 07 Pagi Jakarta Selatan, yaitu pada siklus I pertemuan 1 mencapai nilai rata-rata 62,00 , pada siklus I pertemuan 2 mencapai 67,50, untuk siklus II pertemuan 1 mencapai 76,33 dan siklus II pertemuan 2 mencapai 82,00. Bahkan nilai yang dicapai siswa pada siklus I pertemuan 1 tersebut berada di atas Kriteria Ketuntasan Minimum (KKM) yang ditetapkan di sekolah, yaitu 65. Di samping itu, saran untuk guru yang dapat disampaikan pada kesempatan ini adalah agar dapat menciptakan dan menggunakannya berbagai gambar pemodelan yang variatif untuk menunjang proses pembelajaran, karena pada siklus I maupun siklus II masalah penggunaan gambar pemodelan tersebut masih dianggap lemah; dan 3) Kepada kepala sekolah diharapkan agar dapat menyediakan fasilitas yang menunjang proses pembelajaran terutama penunjang dalam menerapkan pendekatan Contextual Teaching and Learning (CTL). Misalnya, media pembelajaran seperti computer, VCD, infocus, pengeras suara, alat peraga, ruangan praktek/diskusi, bahan ajar baik cetak maupun elektronik, dan sebagainya. Di samping itu, alangkah baiknya kepala sekolah dapat memberikan arahan dan bimbingan kepada guru-guru tentang cara menerapkan pendekatan Contextual Teaching and Learning (CTL), sehingga penerapannya akan lebih tepat dan sesuai prosedur. Di sisi lain, Kepala Sekolah harus memberikan kesempatan kepada semua guru untuk mengikuti pelatihan bidang pendidikan terutama pada pelatihan pembuatan dan penggunaan berbagai gambar pemodelan yang dapat digunakan dalam proses pembelajaran.

\section{DAFTAR PUSTAKa}

Alan, U. F., \& Afriansyah, E. A. (2017). Kemampuan Pemahaman Matematis Siswa melalui Model Pembelajaran Auditory Intellectualy Repetition dan Problem Based Learning. Jurnal Pendidikan Matematika UNSRI, 11(1), 67-78.

https://doi.org/10.22342/jpm.11.1.38 90.67-78

Latipah, E. D. P., \& Afriansyah, E. A. (2018). Analisis Kemampuan Koneksi Matematis Siswa Menggunakan

\section{Mosharafa: Jumal Pendidikan Matematika}


http://journal.institutpendidikan.ac.id/index.php/mosharafa

Pendekatan Pembelajaran CTL dan

RME. Jurnal Matematika, 17(1), 1-12.

Retrieved

https://ejournal.unisba.ac.id/index.ph

$\mathrm{p} /$ matematika/article/view/3691/237

$\underline{0}$

Maryati, I. dan Priatna, N. (2017). Integrasi

Nilai-Nilai Karakter Matematika

melalui Pembelajaran Kontekstual.

Mosharafa: Jurnal Pendidikan

Matematika, 6(3), 333-344.

Muna, D. N., \& Afriansyah, E. A. (2016).

Peningkatan

Kemampuan

Pemahaman Matematis Siswa melalui

Pembelajaran Kooperatif Teknik

Kancing Gemerencing dan Number

Head Together. Mosharafa: Jurnal

Pendidikan Matematika, 5(2), 169-

176.

Nuraeni, Y., \& Afriansyah, E. A. (2016).

Peningkatan

Kemampuan

Pemahaman Matematis Siswa Melalui

Pembelajaran Kooperatif Tipe

Rotating Trio Exchange. Jurnal Inovasi

Pendidikan Dasar, 1(2), 85-94.

Retrieved from

http://jipd.uhamka.ac.id/index.php/jip

d/article/view/24/12

Nurhadi. (2002). Pendekatan Kontekstual.

Jakarta: Departemen Pendidikan

Nasional. Direktorat Jenderal

Pendidikan Dasar Menengah.

Direktorat Pendidikan Lanjutan

Pertama.

Pamungkas, Y., \& Afriansyah, E. A. (2017).

Aptitude Treatment Interaction

terhadap Kemampuan Pemahaman

Matematis Siswa. Jurnal Pendidikan
Matematika RAFA, 3(1), 122-130.

Retrieved

from

http://jurnal.radenfatah.ac.id/index.p

hp/jpmrafa/article/view/1445/1156

Pirdaus, D. A., \& Afriansyah, E. A. (2016).

Pembelajaran Kooperatif Tipe Team

Assisted Individually untuk

Meningkatkan

Kemampuan

Pemahaman Matematis Siswa Sekolah

Menengah Pertama. Jurnal Pendidikan

Matematika RAFA, 2(1), 104-122.

Retrieved

from

http://jurnal.radenfatah.ac.id/index.p

hp/jpmrafa/article/view/1243/1036

Razak, F. dan Kamaruddin, R. (2018).

Pengaruh Sikap IImiah Siswa terhadap

Hasil Belajar Materi Bangun Ruang

Siswa Kelas VIII SMP Negeri 3

Minasatene. Mosharafa: Jurnal

Pendidikan Matematika, 7(1), 133142.

Supriatna, R., \& Afriansyah, E. A. (2018).

Kemampuan Pemahaman MAatematis

Peserta Didik melalui Cooperative

Learning Tipe Pair Checks VS Problem

Based Learning. Jurnal Pendidikan

Matematika Indonesia, 3(1), 1-6.

Retrieved from

http://journal.stkipsingkawang.ac.id/i

ndex.php/JPMI/article/view/450/472

Wahyudin. (2008). Pembelajaran dan

Model-Model Pembelajaran. Jakarta:

Matematika Abong. 